\title{
Ikke kluss med naturen
}

I dette nummer av Tidsskriftet har S. Knudtzon og medarbeidere en informativ artikkel om diagnostikk og behandling av adhesjon av de små kjønnsleppene (1). Selv om tilstanden er ganske vanlig, er den ikke særlig godt kjent hos foreldre og helsepersonell, kanskje fordi et flertall av jentene ikke har symptomer (1-6). Insidensen er i enkelte studier så høy som $20-40 \%$, og én forfatter spør om ikke adhesjon av de små kjønnsleppene bør oppfattes som et normalfunn hos prepubertale jenter (4)? Tilstanden anses å være ervervet, siden den ikke finnes i de tre første levemånedene (6). Ettersom den heller ikke finnes etter puberteten (2-6), antas det at sammenloddingen har sammenheng med det naturlig lave østrogennivået $\mathrm{i}$ årene mellom nyfødtperioden og fertil alder $(2,4-6)$.

Diagnosen stilles enkelt ved inspeksjon. Tilstanden skilles fra vagina som ender blindt, manglende vagina og hymen imperforatum ved at vulva og de små kjønnsleppene her ser normale ut og urinrørsåpningen er synlig (5). Sammenloddingen av de små kjønnsleppene kan på diagnosetidspunktet være ganske fast. Siden tilstandens naturlige forløp er spontan normalisering før puberteten (1-6), vil det selvsagt også finnes jenter med svært lettgradige adhesjoner. Ved første legebesøk kan derfor et forsøk på å trekke kjønnsleppene fra hverandre uten anestesi være fristende. Etter min erfaring bør dette frarådes. Barns smerteopplevelse er individuell, og for mange er bare det å bli holdt skremmende. Det bør være lav terskel for anvendelse av lokalbedøvelse og endatil narkose ved slike anledninger.

I sin studie har kollegene ved St. Olavs hospital vist at resultatene ved både lokal applikasjon av østrogen- eller glukokortikoidkrem og kirurgisk behandling er dårlige - ved behandlingsslutt var sammenloddingen løsnet hos kun litt over halvparten (1). Resultatet er imidlertid i samsvar med litteraturen $(2,6)$. Gitt tilstandens naturlige forløp er det en svakhet ved denne studien at kun åtte av 105 jenter ble observert uten behandling og at kun fire av dem ble fulgt til normalisering. Forfatterne konkluderer likevel med: «Tilstanden går spontant tilbake hos alle, senest i puberteten.» Pasientene ved St. Olavs hospital er ikke fulgt lenge nok til å kunne bekrefte denne påstanden, som imidlertid har solid støtte i litteraturen (2-6). Det konkluderes videre med at observasjon alene bør være første behandlingsvalg hos symptomfrie jenter. Denne anbefalingen synes det også å være bred enighet om (2-6). Ved ledsagende plager som urinveisinfeksjon, uretritt eller vulvovaginitt, derimot, er det vanlig å anbefale at sammenloddingene løsnes $(2-4,6)$. Slike ledsagende tilstander behøver imidlertid ikke å ha noe med adhesjonen å gjøre. Ved det velrenommerte Hôpital Necker-Enfants malades i Paris, der man årlig ser rundt 40 nye tilfeller av denne tilstanden, løsner man ikke sammenloddingene selv hos dem som blir behandlet for de ovenfornevnte sykdommene. Kjønnsleppene åpnes kun når det er behov for tilgang til urinrørsåpningen (f.eks. for cystografi) eller ved lichen sclerosus (5).
Når adhesjon påvises, blir det viktigste å forsikre foreldrene om at det ikke er noen grunn til bekymring, dernest å informere skikkelig om tilstandens naturlige forløp samt poengtere betydningen av god perineal hygiene. Etter mitt syn er ytterligere oppfølging og kontroller av symptomfrie jenter (med eller uten adhesjon) ikke nødvendig. Hos dem med ledsagende symptomer kan behandling bli aktuelt. Da må informasjonen om behandlingsalternativene inkludere omtale av hyppige tilbakefall, både etter medikamentell og kirurgisk behandling (2-4). En forfatter rapporterer tilbakefall hos hele $40 \%$ (6). Det kan også være betenkelig å forskrive en behandling som innebærer at småjenter skal smøres i skrittet to ganger daglig i opptil åtte uker (1). Mange foreldre vil kunne føle seg ubekvemme med denne oppgaven. Alt dette og fordi behandling kan være ubehagelig og ha sidevirkninger (1) taler for å anbefale observasjon som eneste tiltak. Selv om jeg har stor sans for behandlingsprinsippene ved Hôpital Necker (5), har jeg ikke problemer med å akseptere at en del foreldre ser annerledes på saken. Deres ønske om å løsne sammenloddingen, kirurgisk eller medikamentelt, bør da etterkommes, det er tross alt ingen stor sak.

Sammenfatningsvis har Knudtzon og medarbeidere gitt et viktig bidrag til å informere alle som arbeider med småbarn om en vanlig tilstand som affiserer jenters kjønnsorgan og som av og til krever behandling. Men som regel er altså det beste tiltaket å vente på at naturen ordner opp selv.

Tom Monclair

tom.monclair@online.no

Tom Monclair (f. 1942) er dr.med., pensjonert barnekirurg fra Rikshospitalet og seniorforsker.

Forfatter har fylt ut ICMJE-skjemaet og oppgir ingen interessekonflikter.

Litteratur

1. Knudtzon S, Haugen SE, Myhre AK. Adhesjon av de små kjønnsleppene - diagnostikk og behandling. Tidsskr Nor Legeforen 2017; 137: 31-5.

2. Nurzia MJ, Eickhorst KM, Ankem MK et al. The surgical treatment of labial adhesions in pre-pubertal girls. J Pediatr Adolesc Gynecol 2003; 16: 21 -3.

3. McGreal S, Wood PL. A study of paediatric and adolescent gynaecology services in a British district general hospital. BJOG 2010; 117: 1643-50.

4. Omar HA. Management of labial adhesions in prepubertal girls. J Pediatr Adolesc Gynecol 2000; 13: 183-5.

5. Thibaud E, Duflos C. Plaidoyer pour l'enfant: le traitement de la coalescence des petites lèvres est inutile. Arch Pediatr 2003; 10: 465-6.

6. Vilano SE, Robbins CL. Common prepubertal vulvar conditions. Curr Opin Obstet Gynecol 2016; 28: 359-65.

Engelsk oversettelse på www.tidsskriftet.no 